\title{
KIR2DS1 Gene
}

National Cancer Institute

\section{Source}

National Cancer Institute. KIR2DS1 Gene. NCI Thesaurus. Code C106092.

This gene plays a role in the regulation of immune responses. 